\title{
Kinetics of styrene in workers from a plastics industry after controlled exposure: a comparison with subjects not previously exposed
}

\author{
A LÖF, E LUNDGREN, AND M BYFÄLT NORDQVIST \\ From the Research Department, National Board of Occupational Safety and Health, Solna, Sweden
}

ABSTRACT Eight male workers from a glass reinforced plastics industry were experimentally exposed for 2 hours to $2.84 \mathrm{mmol} / \mathrm{m}^{3}\left(296 \mathrm{mg} / \mathrm{m}^{3}\right)$ styrene during light physical exercise $(50 \mathrm{~W})$. About $63 \%$ of the amount supplied $(4.6 \mathrm{mmol}$ styrene) was taken up in the body. The arterial blood concentration of styrene reached a relatively stable level of $15 \mu \mathrm{mol} / 1$ at the end of exposure which was about $70 \%$ of the blood concentration in a group of volunteers with no previous exposure to solvents. The apparent blood clearance was significantly higher in the occupationally exposed subjects $2 \cdot 01 / \mathrm{h} \times \mathrm{kg}$ compared with $1 \cdot 51 / \mathrm{h} \times \mathrm{kg}$. Contrary to the relatively stable level of styrene at the end of exposure the concentration of non-conjugated styrene glycol increased throughout the exposure and reached about $3 \mu \mathrm{mol} / 1$ in both groups. Like styrene, the non-conjugated styrene glycol seemed to be eliminated faster from the occupationally exposed workers. The blood concentration of styrene-7,8-oxide was low and seldom exceeded the detection limit of $0.02 \mu \mathrm{mol} / 1$. The results show that long term exposure in a glass reinforced plastics industry may facilitate the metabolism of styrene.

The most extensive exposures to styrene (vinylbenzene, phenylethylene) occur in plants manufacturing glass reinforced plastics. ${ }^{1}$ During lamination by hand the evaporation of styrene is considerable and $60-70 \%$ of the amount inspired is taken up in the body. ${ }^{2}$

The metabolism of styrene takes place in the liver but extrahepatic metabolism has not been ruled out. $^{3-7}$ The first step in the major metabolic pathway is the formation of styrene-7,8-oxide (phenyloxirane), a reaction preferentially catalysed by microsomal cytochrome P-450.48-10 Styrene-7,8-oxide is hydrated to styrene glycol (1-phenyl-1,2-ethanediol) by microsomal epoxide hydratase and this is conjugated with $\beta$-glucuronic acid or oxidised to mandelic acid and further to phenylglyoxylic acid. In man about $90 \%$ of a styrene dose is eliminated as mandelic and phenylglyoxylic acids in the urine. ${ }^{8}$ The biotransformation may be stimulated by styrene itself, ${ }^{11-13}$ phenobarbital, ${ }^{414}$ or the chronic intake of ethanol ${ }^{15}$; it is inhibited by the coadministration of ethanol, toluene, and trichloroethylene. ${ }^{16-18}$

The main purpose of the present study was to analyse styrene, styrene-7,8-oxide, and styrene glycol in

Accepted 5 December 1985 blood from workers exposed to styrene. We also wished to discover if a long term exposure at a glass reinforced plastics industry modified the elimination of styrene.

\section{Subjects}

The volunteers from a plant manufacturing glass reinforced plastics were eight men with an average age of 34 (range 25-47), an average weight of 76 (range 68-105) kg, and an average height of 178 (range $170-188) \mathrm{cm}$. The amount of body fat of the respective subjects was estimated by means of anthropometric measurements. ${ }^{19}$ The mean amount of adipose tissue in the subjects, 18 (SD 13) kg, was estimated from the total amount of body fat on the assumption that the average fat content of adipose tissue is $80 \% .^{20}$ None of the workers was taking medication or had suffered from any disease having a detrimental effect on the function of the respiratory and circulatory organs. They had been employed for seven to 12 years. Four were smokers and three used snuff. The consumption of ethanol was considered moderate. The styrene exposure in the plant ranged from 5 to $125 \mathrm{mg} / \mathrm{m}^{3}$ with a mean level of $44.4 \mathrm{mg} / \mathrm{m}^{3}$ during a week with normal work intensity. 
Unsaturated polyester resins containing about $40 \%$ styrene as a reactive diluent were used. Organic peroxides were added to regulate the exothermic hardening reaction and acetone was used for cleaning tools.

The volunteers with no previous exposure to solvents ${ }^{2}$ were eight healthy men with an average age of 27 (range 23-34), an average weight of 71 (range $60-80) \mathrm{kg}$, an average height of 179 (range $174-191) \mathrm{cm}$, and a mean amount of adipose tissue of 12 (SD 7) kg. Three were smokers and the consumption of ethanol was low. None was taking any medicine.

\section{Methods}

The experimental exposure of workers took place on a Friday morning after occupational exposure during the preceding days of the week. The subjects were exposed in pairs for two hours to a styrene concentration of 2.84 (SD 0.07$) \mathrm{mmol} / \mathrm{m}^{3}\left(296 \mathrm{mg} / \mathrm{m}^{3}\right)$ (Merck, analytical grade). The Swedish short term exposure limit concentration is $2.88 \mathrm{mmol} / \mathrm{m}^{3}$ $\left(300 \mathrm{mg} / \mathrm{m}^{3}\right)$. The exposures were performed in an exposure chamber (volume $12 \mathrm{~m}^{3}$, air change 10 times $/ \mathrm{h}$, inlet air flow $115 \mathrm{~m}^{3} / \mathrm{h}$, outlet air flow $135 \mathrm{~m}^{3} / \mathrm{h}$ ) during light physical exercise (work load of $50 \mathrm{~W}$ ) on a bicycle ergometer. Solvent was injected in the influent air stream by means of a high performance liquid chromatography pump (Gilson 302) and the concentration in the chamber was continuously monitored by an infrared spectrophotometer (Miran IA) at $11 \cdot 1 \mu \mathrm{m}$, sampling air from the upper central section of the chamber. The air in the chamber was at the desired concentration when the volunteers entered. The exposure of the reference subjects took place in the same exposure chamber under identical conditions $\left(2 \mathrm{~h}, 2.84 \mathrm{mmol} / \mathrm{m}^{3}, 50 \mathrm{~W}\right)$ and has been described earlier. ${ }^{2}$

The respiratory uptake of styrene was determined in each individual using the Douglas bag technique. The exhaled air was collected during four minutes at regular intervals, and the uptake during each 30 minute period was calculated from the mean value of two sampling periods during this time. The methods for determining the styrene concentration in the inspired and expired air and the measurements of the solvent uptake were basically the same as described elsewhere. ${ }^{21}$ The error of the method was estimated to be $\pm 3 \%$.

Arterial blood samples were withdrawn from a catheter introduced into a brachial artery. For the analysis of styrene in blood, samples of $1 \mathrm{ml}$ were equilibrated with air at $37^{\circ} \mathrm{C}$ for 20 minutes in citrate treated headspace bottles. Headspace air was analysed for styrene by gas chromatography (3\% SE-30 on Chromosorb GAW, $2.0 \mathrm{~m}, 130^{\circ} \mathrm{C}$, nitrogen flow $20 \mathrm{ml} / \mathrm{min}$, flame ionisation detector, Perkin Elmer $\mathrm{F}$ 45). The peak area was integrated (Varian Vista 401 chromatography data system). Individual calibration curves were obtained by adding $2 \mu \mathrm{l}$ of standard solutions of styrene in dimethylsulphoxide (Merck, analytical grade) to blood sampled before exposure $(2 \mu \mathrm{l}$ of dimethylsulphoxide was added to all samples taken during and after exposure). The error of the method at concentrations below $6 \mu \mathrm{mol} / 1$ was estimated to be $\pm 7 \%$.

An apparent styrene clearance, $\mathrm{Cl}_{\text {app }}$, was calculated for each subject as the dose of styrene divided by AUC (area under the blood concentration versus time curve). The total uptake was regarded as the dose as the solvent rapidly diffuses into the blood. AUC for the exposure period was calculated by the trapezoidal rule. For the elimination phase, AUC was calculated by integration of the equation, $y=A \cdot e^{-\alpha t}+B \cdot e^{-\beta t}$ where $\mathrm{y}$ is the solvent concentration in the blood, $\mathrm{t}$ represents the time, $\mathrm{A}$ and $\mathrm{B}$ are the $\mathrm{y}$ intercepts, and $\alpha$ and $\beta$ are the slopes of the lines.

Styrene-7,8-oxide and styrene glycol in blood were analysed after an extraction procedure (fig 1). Each blood sample $(2 \mathrm{ml})$ was extracted with hexane (Merck, analytical grade) to remove styrene-7,8-oxide

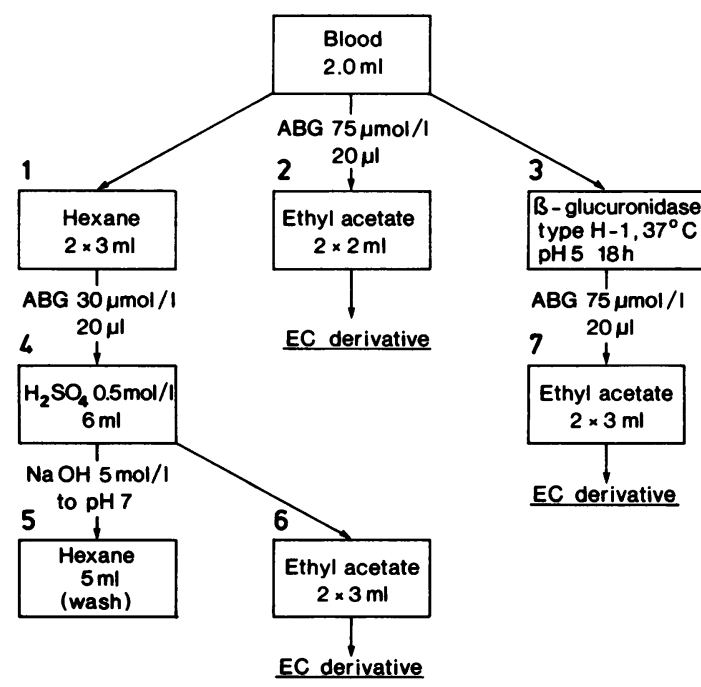

Fig 1 Scheme for extraction of styrene-7,8-oxide (step 1), styrene glycol (step 2), and conjugated styrene glycol (step 3) from blood. Allylbenzene glycol ( $A B G$ ) was used as an internal standard. Styrene-7,8-oxide was hydrolysed with sulphuric acid $\left(\mathrm{H}_{2} \mathrm{SO}_{4}\right)$ to styrene glycol (step 4). Ethyl acetate extracts were treated with pentafluorobenzoyl chloride and analysed by gas liquid chromatography with an electron capture detector (EC). (NaOH = sodium hydroxide.) 
(fig 1, step 1) and then with ethyl acetate (Merck, analytical grade) to remove styrene glycol (fig 1, step 2). Conjugated styrene glycol was cleaved with $\beta$-glucuronidase type $\mathrm{H}-1$ (Sigma) in $0.07 \mathrm{M}$ acetate buffer pH 5.0 at $37^{\circ} \mathrm{C}$ overnight (fig 1, step 3). Allylbenzene glycol (synthesised according to Duverger-van Bogaert et $a l)^{22}$ was added as the internal standard before the extraction with ethyl acetate. Acidification converted styrene-7,8-oxide to styrene glycol (fig 1, step 4). The ethyl acetate extracts were derivatised with pentafluorobenzoyl chloride (Aldrich $98 \%$ ) and analysed by a gas chromatographic technique based on electron capture detection. ${ }^{22}$ In the determination of styrene-7,8-oxide and nonconjugated styrene glycol the conditions were: $3 \%$ SE-30 on Chromosorb GAW-DMCS, $2.0 \mathrm{~m}, 220^{\circ} \mathrm{C}$, nitrogen flow $50 \mathrm{ml} / \mathrm{min}$, Carlo Erba FTV 2350. Both styrene-7,8-oxide and enzymatically liberated styrene glycol were analysed on a capillary column (BP-1$0.25,0.2 \mathrm{~mm} \times 12 \mathrm{~m}, 230^{\circ} \mathrm{C}$, helium flow $1.5 \mathrm{ml} / \mathrm{min}$, Carlo Erba FTV 2350). The peak areas were integrated (Varian Vista 401 chromatography data system). Calibration curves were obtained by adding $10 \mu \mathrm{l}$ of standard solutions of styrene-7,8-oxide (Fluka AG, Buchs SG $>97 \%$ purity, distilled) or styrene glycol (Aldrich, $97 \%$ purity) in toluene to blood before extraction. The blood concentration range was $0-1 \mu \mathrm{mol} / 1$ for styrene-7,8-oxide, $0-10 \mu \mathrm{mol} / 1$ for styrene glycol, and $0-1 \mu \mathrm{mol} / 1$ for conjugated styrene glycol. The calibration curves were linear for the concentration range in question and could be applied down to a concentration of $0.02 \mu \mathrm{mol} / 1$ for styrene7,8-oxide, $0.08 \mu \mathrm{mol} / 1$ for styrene glycol, and $0.02 \mu \mathrm{mol} / 1$ for conjugated styrene glycol. No detectable contamination with styrene glycol in the hexane extract occurs in the actual concentration range. ${ }^{2}$ The error of the estimation of styrene glycol was $\pm 15 \%$ at concentrations below $1 \mu \mathrm{mol} / 1$ and $\pm 7 \cdot 3 \%$ at concentrations between $1 \cdot 5-5 \cdot 1 \mu \mathrm{mol} / \mathrm{l}$.

The calculation of the errors of the methods for a single determination was based on the differences between double determinations and expressed as the percentage of the value of the mean. The significance of differences between mean values was tested by Student's $t$ test for independent observations; $p<0.05$ was chosen as the level of significance.

\section{Results}

The total uptake of styrene in the pre-exposed volunteers was 4.6 (SD 0.5) mmol or 63 (SD 3)\% of the amount supplied (table 1). The relative uptake was significantly lower than that found in the nonoccupationally exposed subjects but a higher pulmonary ventilation per time unit equalised the total uptake.

At the start of the exposure the arterial blood concentration of styrene was 0.3 (SD 0.2 ) $\mu \mathrm{mol} / 1$ in the occupationally pre-exposed subjects (fig 2 ). A steady state level was almost reached after. 75 minutes of exposure as seen previously in the reference group. The styrene concentration was significantly lower in the pre-exposed group both during the exposure and the following 30 minutes. At the termination of exposure the mean concentration was 14.7 (SD 2.9) $\mu \mathrm{mol} / 1$ in the pre-exposed group and 21.2 (SD 6.9) $\mu \mathrm{mol} / 1$ in the reference group (table 2 ). The pre-

Table 1 Values of pulmonary ventilation $\left(\dot{V}_{\mathrm{E}}\right)$, inhaled amount of styrene, total uptake of styrene $\left(U_{t}\right)$, and the relative uptake of styrene $(F)$ for each 30 minute period

\begin{tabular}{|c|c|c|c|c|c|c|c|c|}
\hline \multirow[t]{2}{*}{$\begin{array}{l}\text { Time period } \\
(\mathrm{min})\end{array}$} & \multicolumn{2}{|c|}{$\begin{array}{l}V_{E} B T P S^{*} \\
\left(\eta_{\text {min }}\right)(n=8)\end{array}$} & \multicolumn{2}{|c|}{$\begin{array}{l}\text { Inhaled amount } \\
(\text { mmol })(n=8)\end{array}$} & \multicolumn{2}{|c|}{$\begin{array}{l}\text { Uptake }\left(U_{t}\right) \dagger \\
(m m o l)(n=8)\end{array}$} & \multicolumn{2}{|c|}{$\begin{array}{l}\text { Uptake in } \% \text { of the inhaled } \\
\text { amount }(F) \ddagger(n=8)\end{array}$} \\
\hline & Mean & $S D$ & Mean & $S D$ & Mean & $S D$ & Mean & $S D$ \\
\hline \multicolumn{9}{|c|}{ Pre-exposed subjects } \\
\hline $\begin{array}{l}0-30 \\
30-60 \\
60-90 \\
90-120\end{array}$ & $\begin{array}{l}23 \cdot 2 \\
23 \cdot 2 \\
23 \cdot 5 \\
23 \cdot 7\end{array}$ & $\begin{array}{l}2 \cdot 6 \\
2 \cdot 3 \\
2 \cdot 0 \\
2 \cdot 2\end{array}$ & $\begin{array}{l}1.83 \\
1.81 \\
1.82 \\
1.84\end{array}$ & $\begin{array}{l}0.22 \\
0.17 \\
0.17 \\
0.19\end{array}$ & $\begin{array}{l}1 \cdot 19 \\
1.14 \\
1 \cdot 12 \\
1 \cdot 12\end{array}$ & $\begin{array}{l}0.12 \\
0.12 \\
0.13 \\
0.13\end{array}$ & $\begin{array}{l}65 \cdot 7 \\
62 \cdot 9 \\
61 \cdot 3 \\
60 \cdot 5\end{array}$ & $\begin{array}{l}2 \cdot 5 \\
3 \cdot 1 \\
3 \cdot 1 \\
2 \cdot 8\end{array}$ \\
\hline $0-120$ & $23 \cdot 4$ & $2 \cdot 1$ & $7 \cdot 31$ & 0.68 & $4 \cdot 57$ & 0.46 & $62 \cdot 6$ & $2 \cdot 8$ \\
\hline \multicolumn{9}{|c|}{ Reference subjects ${ }^{2}$} \\
\hline $\begin{array}{l}0-30 \\
30-60 \\
60-90 \\
90-120\end{array}$ & $\begin{array}{l}19 \cdot 8 \\
20 \cdot 6 \\
20 \cdot 6 \\
21 \cdot 5\end{array}$ & $\begin{array}{l}2 \cdot 6 \\
2 \cdot 4 \\
2 \cdot 2 \\
2 \cdot 9\end{array}$ & $\begin{array}{l}1.56 \\
1.64 \\
1.65 \\
1.71\end{array}$ & $\begin{array}{l}0.20 \\
0.20 \\
0.18 \\
0.25\end{array}$ & $\begin{array}{l}1 \cdot 10 \\
1 \cdot 10 \\
1 \cdot 11 \\
1 \cdot 13\end{array}$ & $\begin{array}{l}0 \cdot 14 \\
0 \cdot 12 \\
0 \cdot 14 \\
0 \cdot 17\end{array}$ & $\begin{array}{l}70 \cdot 9 \\
67 \cdot 3 \\
67 \cdot 3 \\
66 \cdot 1\end{array}$ & $\begin{array}{l}3.9 \\
4.2 \\
4.6 \\
5.0\end{array}$ \\
\hline $0-120$ & $20 \cdot 6$ & $2 \cdot 2$ & $6 \cdot 56$ & 0.73 & $4 \cdot 44$ & 0.52 & 67.9 & $4 \cdot 3$ \\
\hline
\end{tabular}

$* \dot{V}_{E} B T P S=$ pulmonary ventilation per time unit, $37^{\circ} \mathrm{C}$ ambient pressure, saturated with water.

$+U_{t}=\dot{V}_{E} \times t \times\left(C_{i n}-C_{e z}\right) ; t=$ duration of exposure, $C_{i n}=$ solvent concentration in inspired air, $C_{e x}=$ solvent concentration in expired air. $\ddagger F^{t}=\left(C_{i n}-C_{e x}\right) \times 100 / C_{i n}$. 
Fig 2 Concentration of styrene in arterial blood during and after exposure to styrene for two hours during physical exercise with a work load of $50 \mathrm{~W} .(\mathrm{O})$ represents mean values and standard deviations for eight male workers from a glass reinforced plastics industry after exposure to $2.84 \mathrm{mmol} / \mathrm{m}^{3}$ styrene. (O) represents mean values for seven male volunteers not earlier exposed to solvents after exposure to $2 \cdot 88 \mathrm{mmol} / \mathrm{m}^{3}$ styrene.

Table 2 Arterial blood concentrations of styrene and non-conjugated styrene glycol at the end of exposure, apparent styrene clearance $\left(C l_{a p p}\right)$ and half time of non-conjugated styrene glycol in arterial blood $\left(t_{1 / 2} S G\right)$

\begin{tabular}{|c|c|c|c|c|}
\hline & \multicolumn{2}{|c|}{ Pre-exposed subjects $(n=8)$} & \multicolumn{2}{|c|}{ Reference subjects ${ }^{2}(n=7)$} \\
\hline & Mean & $S D$ & Mean & $S D$ \\
\hline $\begin{array}{l}\text { Styrene }(\mu \mathrm{mol} / \mathrm{l}) \\
\text { Non-conjugated styrene }\end{array}$ & $14 \cdot 7$ & $2 \cdot 9$ & $21 \cdot 2$ & 6.9 \\
\hline $\mathrm{Cl}_{\mathrm{app}}^{\mathrm{glycol}(\mu \mathrm{mol} / \mathrm{h} \cdot \mathrm{kg}}$ & $\begin{array}{l}2 \cdot 8 \\
2 \cdot 0\end{array}$ & $\begin{array}{l}0.96 \\
0.4\end{array}$ & $\begin{array}{l}3.0 \\
1.5\end{array}$ & $\begin{array}{l}1 \cdot 1 \\
0 \cdot 3\end{array}$ \\
\hline $\mathrm{t}_{1 / 2} \mathrm{SG}(\mathrm{min})$ & $47 \cdot 0$ & $13 \cdot 3$ & $72 \cdot 1$ & $13 \cdot 3$ \\
\hline
\end{tabular}

exposed group had a significantly higher apparent clearance 2.0 (SD 0.4) $\mathrm{l} / \mathrm{h} \cdot \mathrm{kg}$ compared with 1.5 (SD $0 \cdot 3$ ) $\mathrm{l} / \mathrm{h} \cdot \mathrm{kg}$ for the reference group (table 2 ).

The concentration of non-conjugated styrene glycol in the blood rose continuously during the exposure and reached about $3 \mu \mathrm{mol} / 1$ irrespective of pre-exposure (fig 3 , table 2 ). One to two hours after the termination of exposure the concentration of nonconjugated styrene glycol was significantly lower in the occupationally pre-exposed group. The elimination of styrene glycol was considered to be monoexponential. The mean $t_{1 / 2}$ was significantly lower than that reported for the reference group (table 2). The amount of styrene glycol conjugated with $\beta$-glucuronic acid was significantly higher in the pre- $\sigma$ exposed group compared with the reference group $N$ both during and after the exposure (table 3 ). When $N$ the total concentration of styrene glycol was compared, no significant difference was noted in the two groups.

A maximum concentration of styrene-7,8-oxide $\stackrel{\wp}{\rightleftharpoons}$ was determined to $0.03 \mu \mathrm{mol} / 1$, both with the packed and the capillary columns, in the pre-exposed subjects. 


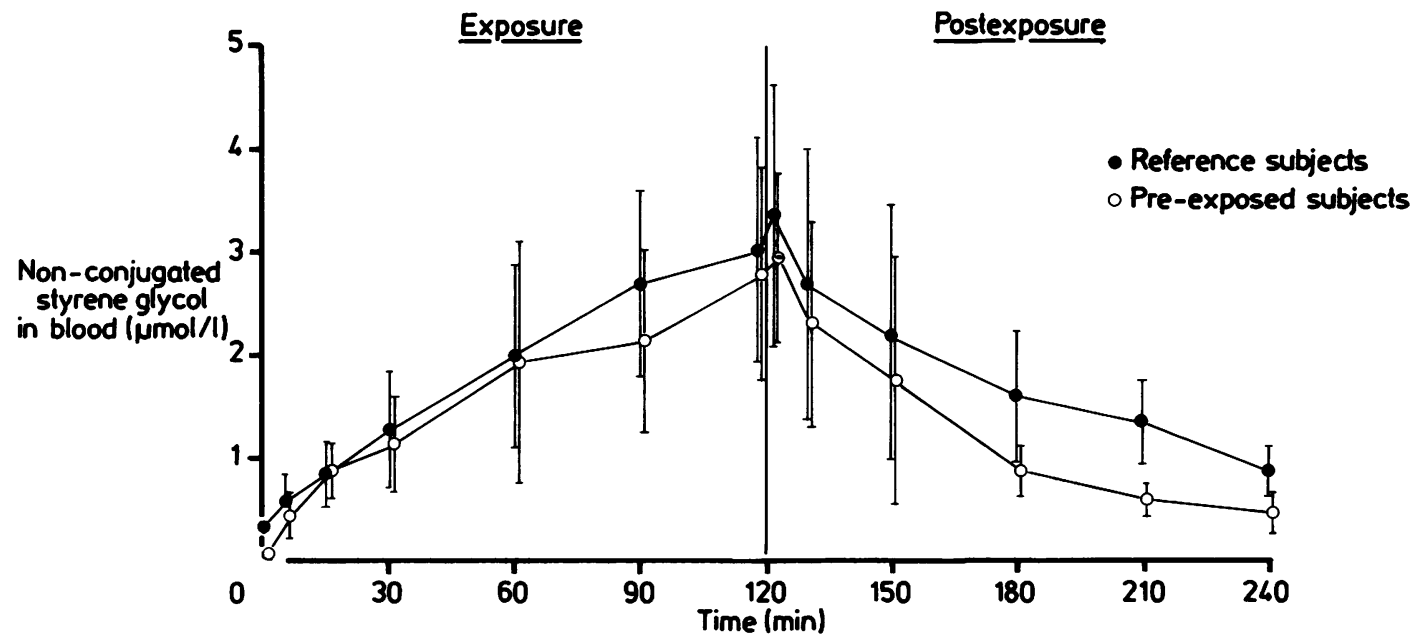

Fig 3 Concentration of non-conjugated styrene glycol in arterial blood during and after exposure to styrene for two hours during physical exercise with a work load of $50 \mathrm{~W}$. (O) represents mean values and standard deviations for seven male workers from a glass reinforced plastics industry after exposure to $2.84 \mathrm{mmol} / \mathrm{m}^{3}$ styrene. (O) represents mean values for seven male volunteers not earlier exposed to solvents after exposure to $2 \cdot 88 \mathrm{mmol} / \mathrm{m}^{3}$ styrene.

Table 3 Percentage of styrene glycol conjugated with $\beta$-glucuronic acid

\begin{tabular}{lll}
\hline $\begin{array}{l}\text { Time (min) } \\
\text { (after onset } \\
\text { of exposure) }\end{array}$ & $\begin{array}{l}\text { Pre-exposed } \\
\text { subjects }(\%) \\
(n=7)\end{array}$ & $\begin{array}{l}\text { Reference } \\
\text { subjects }(\%) \\
(n=7)\end{array}$ \\
\hline 60 & $40.8 \pm 18.5$ & $21 \cdot 3 \pm 5.8$ \\
120 & $41.9 \pm 11.5$ & $21.9 \pm 5.9$ \\
180 & $59.6 \pm 13.8$ & $21.8 \pm 7.9$ \\
240 & $62.8 \pm 9.4$ & $27.3 \pm 8.4$ \\
\hline
\end{tabular}

\section{Discussion}

The relative uptake of styrene in the occupationally exposed subjects was similar to that reported earlier after occupational exposure ${ }^{23}$ and lower than that found in subjects with no previous exposure. To some extent the difference in the relative uptake may be explained by the difference in pulmonary ventilation and in age. If dependent on the history of exposure it may be caused by different adsorption on and desorption from the walls of respiratory airways. ${ }^{24}$

A significantly lower blood concentration over time in the pre-exposed subjects as compared with the reference group after identical external exposure and total uptake must result from an increased clearance or a higher volume of distribution of styrene in the former subjects. Ramsey et al have reported a half time of 13 hours for the terminal phase ${ }^{25} 26$ which means that the area under the blood concentration versus time curve is underestimated and consequently $\mathrm{Cl}_{\text {app }}$ exceeds systemic clearance. The calculated $\mathrm{Cl}_{\text {app }}$ values for styrene are of the same order as the total blood flow through the liver. ${ }^{27}$ Extrahepatic metabolism ${ }^{3-7}$ and uptake by adipose tissues may also contribute to the apparent clearance. Most tissues, except adipose tissue, may be considered almost equilibrated with regard to styrene at the end of a two hour exposure at $50 \mathrm{~W}$. In the reference study the concentration of styrene in adipose tissue was measured and the systemic clearance calculated to be $1 \cdot 31 / \mathrm{h} \cdot \mathrm{kg} .^{2}{ }^{28} \mathrm{~A}$ similar clearance value was obtained from the data presented by others. ${ }^{26} 29$ The systemic clearance for the pre-exposed group may be calculated to be $1.81 / \mathrm{h} \cdot \mathrm{kg}$ assuming a corresponding distribution of styrene to adipose tissue as in the reference group - that is, $10-15 \%$ of the total uptake. ${ }^{2}$ The stated difference in amount of adipose tissue between the groups was eliminated if the most obese subject was excluded. Then the amount of adipose tissue was 14 (SD 6) kg. This indicates that the higher clearance in the pre-exposed subjects did not depend on distribution to adipose tissue. In the group as a whole a tendency towards higher clearance in lean subjects was observed. The subject in the pre-exposed group with the largest amount of adipose tissue had the lowest clearance. An increased clearance due to facilitated metabolism was also supported by the fact that the lowest clearance was seen in the oldest workers. No tendency for a higher clearance in smokers was seen.

A higher systemic clearance of styrene in the preexposed group may reflect a metabolic adaptation of the body. A decreased accumulation of styrene in rat 
tissue has been shown after prolonged exposure and a decreased half time of mandelic acid excretion in workers exposed to high styrene concentrations $\left(>600 \mathrm{mg} / \mathrm{m}^{3}\right) \cdot{ }^{30-33}$ Because of the long half time of styrene in subcutaneous adipose tissue, 2.2-5.2 days, ${ }^{23} 34$ the workers are continuously exposed to styrene. The concentration of styrene in adipose tissue has actually been shown to increase during a working week. ${ }^{23}$

During exposure the concentration of nonconjugated styrene glycol in the blood was similar in both the pre-exposed and the reference group but after the exposure had ceased a more rapid elimination was seen in the pre-exposed group. One route of elimination is conjugation with glucuronic acid and this glucuromide accumulated in the pre-exposed subjects may be due to an increased activity of UDPglucuronosyltransferase. Daily intraperitoneal doses of $500 \mathrm{mg} / \mathrm{kg}$ of styrene or inhalation of $450 \mathrm{ppm}$ of styrene for seven days increase the activity of UDPglucuronosyltransferase in the rat liver. ${ }^{12}{ }^{13}$ It is not possible to say if there was also an accumulation or a facilitated production of the oxidised products of styrene glycol as these acidic metabolites were not analysed.

The concentration of styrene-7,8-oxide was low and never exceeded $0.03 \mu \mathrm{mol} / 1$ in the blood of the occupationally exposed group. The lower limit for detection was estimated to be $0.02 \mu \mathrm{mol} / 1$ depending on some blood component with the same retention time both on the packed and the capillary column. Enzymatic studies in rats have shown an increased activity of epoxide hydratase after exposure to styrene. ${ }^{1335}$ If this is applicable to man styrene-7,8oxide levels would be expected to decrease more quickly after long term exposure to styrene.

These results show that long term exposure at a glass reinforced plastics industry may facilitate the metabolism of styrene. Both styrene and nonconjugated styrene glycol were eliminated faster from occupationally exposed workers than from volunteers with no previous exposure to solvents. Nevertheless, it cannot be excluded that some component other than styrene in the work environment-for example acetone $^{11}$ or other factors-may contribute to the higher clearance of the solvent.

We are very grateful to Ms E M Nydahl and Dr P H Näslund for technical help and to Ms M B Cedervall for preparing the manuscript. We also thank Professor I Åstrand for valuable discussions.

\section{References}

${ }^{1}$ Tossavainen A. Styrene use and occupational exposure in the plastics industry. Scand J Work Environ Health 1978;4,suppl 2:7-13.
${ }^{2}$ Wigaeus E, Löf A, Bjurström R, Byfält Nordqvist M. Exposure to $\frac{\bar{D}}{\mathrm{C}}$ styrene: uptake, distribution, metabolism and elimination in man. Scand J Work Environ Health 1983;9:479-88.

${ }^{3}$ Cantoni L, Salmona M, Facchinetti T, Pantarotto C, Belvedere G. $\overrightarrow{\overline{\mathrm{N}}}$ Hepatic and extrahepatic formation and hydration of styrene $\overrightarrow{+}$ oxide in vitro in animals of different species and sex. Toxicol Lett 1978;2:179-86.

${ }^{4}$ Pantarotto C, Salmona M, Szczawinska K, Bidoli F. Gas chromatographic-mass spectrometric studies on styrene toxicity. $\mathbb{D}$ In: A'lbaiges J, ed. Analytical techniques in environmental chem- $Q$ istry. Oxford: Pergamon Press, 1980:245-79.

${ }^{5}$ Ryan AJ, James MO, Ben-Zvi Z, Law FCP, Bend JR. Hepatic and extrahepatic metabolism of $14 \mathrm{C}$-styrene oxide. Environ Health Perspect 1976;17:135-44.

${ }^{6}$ Salmona M, Pachecka J, Cantoni L, Belvedere G, Mussini E, Gar- $\vec{\omega}$ attini $S$. Microsomal styrene mono-oxygenase and styrene $\sigma$ epoxide hydrase activities in rats. Xenobiotica 1976;6:585-91.

${ }^{7}$ Vainio H, Tursi F, Belvedere G. What are the significant toxic $\frac{\mathbb{D}}{3}$ metabolites of styrene? In: Hietanen E, Laitinen M, Hänninen $\mathrm{O}$, eds. Cytochrome P-450, biochemistry, biophysics and environ- $\omega$ mental implications. Amsterdam: Elsevier Biomedical Press BV, $\infty$ 1982:679-87.

${ }^{8}$ Vainio H, Hietanen E, Belvedere G. Pharmacokinetics and metabolism of styrene. In: Bridges JW, Chasseaud LF, eds. Progress in $\mathrm{O}$ drug metabolism. Vol 8. London: Taylor \& Francis Ltd, 1984:203-39.

${ }^{9}$ Löf A, Gullstrand E, Lundgren E, Byfält Nordqvist M. Occurrence of styrene-7,8-oxide and styrene glycol in mouse after the administration of styrene. Scand J Work Environ Health 1984;10: 179-87.

${ }^{10}$ Watabe T, Isobe M, Yoshikawa K, Takabatake E. Studies on $\vec{\emptyset}$ metabolism and toxicity of styrene: I Biotransformation of sty- $\sigma$ rene to styrene glycol via styrene oxide by rat liver microsomes. Journal of Pharmacobiodynamics 1978;1:98-104.

${ }^{11}$ Dolara P, Lodovici M, Salvadori M, et al. Enzyme induction in humans exposed to styrene. Ann Occup Hyg 1983;27:183-8.

12 Parkki MG, Marniemi J, Vainio H. Action of styrene and its metabolites styrene oxide and styrene glycol on activities of 응 xenobiotic biotransformation enzymes in rat liver in vivo. Toxicol Appl Pharmacol 1976;38:59-70.

${ }^{13}$ Sandell J, Parkki MG, Marniemi J, Aitio A. Effects of inhalation and cutaneous exposure to styrene on drug metabolizing 3 enzymes in the rat. Res Commun Chem Pathol Pharmacol 1978;19:109-18.

${ }^{14}$ Ohtsuji H, Ikeda M. The metabolism of styrene in the rat and the stimulatory effect of phenobarbital. Toxicol Appl Pharmacol $\stackrel{\square}{\triangle}$ 1971;18:321-8.

${ }^{15}$ Sato A, Nakajima T, Koyama Y. Effects of chronic ethanol consumption on hepatic metabolism of aromatic and chlorinated 3 hydrocarbons in rats. Br J Ind Med 1980;37:382-6.

${ }^{16}$ Ikeda M, Hirayama T. Possible metabolic interaction of styrene 0 with organic solvents. Scand J Work Environ Health 1978;4: 41-6.

${ }^{17}$ Ikeda M, Ohtsuji H, Imamura T. In vivo suppression of benzene and styrene oxidation by co-administered toluene in rats and $\frac{D}{O}$ effect of phenobarbital. Xenobiotica 1972;2:101-6.

18 Wilson HK, Robertson SM, Waldron HA, Gompertz D. Effect of alcohol on the kinetics of mandelic acid excretion in volunteers $\sigma$ exposed to styrene vapour. $\mathrm{Br} J$ Ind Med 1983;40:75-80.

${ }^{19}$ Döbeln W von. Anthropometric determination of fat free body weight. Acta Med Scand 1959;165:37-40.

${ }^{20}$ Garrow JS. Energy balance and obesity in man. Amsterdam \& London: North-Holland Publishing Co, 1972:232-4.

${ }^{21}$ Åstrand I, Kilbom $\AA$, Ơvrum P, Wahlberg I, Vesterberg $O$. Exposure to styrene: I concentration in alveolar air and blood at $\mathbb{D}$ rest and during exercise and metabolism. Work Environ Health $\stackrel{+}{-}$ 1974;11:69-85.

${ }^{22}$ Duverger-van Bogaert M, Nöel G, Rollman B, Cumps J, Roberfroid $M$, Mercier $M$. Determination of oxide synthetase and $\overrightarrow{\mathbb{D}}$ hydratase activities by a new highly sensitive gas chromato- 
graphic method using styrene and styrene oxide as substrates. Biochim Biophys Acta 1978;526:77-84.

${ }^{23}$ Engström J, Åstrand I, Wigaeus E. Exposure to styrene in a polymerization plant: uptake in the organism and concentration in subcutaneous adipose tissue. Scand $J$ Work Environ Health 1978;4:324-9.

${ }^{24}$ Fiserova-Bergerova V. Physiological models for pulmonary administration and elimination of inert vapors and gases. In: Fiserova-Bergerova V, ed. Modeling of inhalation exposure to vapors: uptake, distribution, and elimination. Vol 1. Boca Raton, Florida: CRC Press Inc, 1983:73-100.

${ }^{25}$ Ramsey JC, Young JD. Pharmacokinetics of inhaled styrene in rats and humans. Scand J Work Environ Health 1978;4,suppl 2:84-91.

${ }^{26}$ Ramsey JC, Young JD, Karbowski RJ, Chenoweth MB, McCarty LP, Braun WH. Pharmacokinetics of inhaled styrene in human volunteers. Toxicol Appl Pharmacol 1980;53:54-63.

${ }^{27}$ Åstrand I. Effect of physical exercise on uptake, distribution and elimination of vapors in man. In: Fiserova-Bergerova V, ed. Modeling of inhalation exposure to vapors: uptake, distribution, and elimination. Vol 2. Boca Raton, Florida: CRC Press Inc, 1983:107-30.

${ }^{28}$ Wigaeus E. Kinetics of acetone and styrene in inhalation exposure. Arbete och Hälsa 1983;23:1-63. (Doctoral thesis.)

${ }^{29}$ Droz PO, Fernandez JG. Effect of physical workload on retention and metabolism of inhaled organic solvents. A comparative the- oretical approach and its applications with regards to exposure monitoring. Int Arch Occup Environ Health 1977;38:231-46.

${ }^{30}$ Andersen ME, Gargas ML, Ramsey JC. Inhalation pharmacokinetics: evaluating systemic extraction, total in vivo metabolism, and the time course of enzyme induction for inhaled styrene in rats based on arterial blood: inhaled air concentration ratios. Toxicol Appl Pharmacol 1984;73:176-87.

${ }^{31}$ Elovaara E, Vainio H, Pfäffli P, Collan Y. Effects of intermittent styrene inhalation, ethanol intake, and their combination on drug biotransformation in rat liver and kidneys. Med Biol 1979;57:321-7.

${ }^{32}$ Engström K, Härkönen H, Kalliokoski P, Rantanen J. Urinary mandelic acid concentration after occupational exposure to styrene and its use as a biological exposure test. Scand $J$ Work Environ Health 1976;2:21-6.

${ }^{33}$ Savolainen H, Pfäffli P. Effects of chronic styrene inhalation on rat brain protein metabolism. Acta Neuropath (Berl) 1977;40: 237-41.

${ }^{34}$ Engström J, Bjurström R, Åstrand I, Övrum P. Uptake, distribution and elimination of styrene in man: concentration in subcutaneous adipose tissue. Scand J Work Environ Health 1978;4:315-23.

${ }^{35}$ Lambotte-Vandepaer M, Duverger-van Bogaert M, De Meester C, et al. Styrene induced modifications of some rat liver enzymes involved in the activation and inactivation of xenobiotics. Biochem Pharmacol 1979;28:1653-9.

\section{Correspondence and editorials}

The British Journal of Industrial Medicine welcomes correspondence relating to any of the material appearing in the journal. Results from preliminary or small scale studies may also be published in the correspondence column if this seems appropriate. Letters should be not more than 500 words in length and contain a minimum of references. Tables and figures should be kept to an absolute minimum. Letters are accepted on the understanding that they may be subject to editorial revision and shortening.

The journal now also publishes editorials which are normally specially commissioned. The Editor welcomes suggestions regarding suitable topics; those wishing to submit an editorial, however, should do so only after discussion with the Editor. 